\title{
Early prediction of some kid body dimensions from maternal traits
}

\author{
A.H. Salim ${ }^{*}$, A.A. Mnati ${ }^{2}$ and Y.T. Abdul-Rahman ${ }^{3}$ \\ ${ }^{1}$ College of Agriculture, Thi-qar University, Thi-qar, ${ }^{2}$ College of Veterinary, Karbala University, Karbala, \\ ${ }^{3}$ College of Veterinary, University of Fallujah, Fallujah, Iraq, "email:abdelalmaliki@yahoo.com \\ ${ }^{2}$ Current address: College of Sciences, Al-Karkh University of Sciences, Baghdad, Iraq
}

(Received May 29, 2018; Accepted August 17, 2018)

\begin{abstract}
This study was conducted in the Iraqi Ministry of Agriculture, Ruminant Research Station, west of Baghdad. It included 447 goats born of both sexes belonging to local, Shami and their crosses. The body dimensions of kids at birth and the dam's weight and age at birth, as well as the dependence of weaning weight on the birth weight of the kids by the use of simple linear regression equations. The results presented that coefficient of regression of most studied dimensions on the traits of maternal weight at birth and weight of the kid at birth has significant effect, except the regression of the body length at birth on both the maternal weight at birth and the kids weight at birth, which was not significant, The results showed the possibility of dependence on the studied maternal characteristics and kids birth weight to predict the dimensions of the goat kids body at birth.
\end{abstract}

Keywords: Prediction equations, Body dimensions, Goat kids

Available online at http://www.vetmedmosul.com

$$
\begin{aligned}
& \text { توقع بعض أبعاد الجسم لمواليا الماعز من صفات الام والمواليد المبكرة } \\
& \text { عبدالله حميد سالم'، أحمد عبدالرضا مناتي و ياسين طه عبدالرحمن” } \\
& \text { ' كلية الزر اعة، جامعة ذي قار ، ذي قار، ‘ كلية الطب البيطري، جامعة كربلاء، كربلاء، }
\end{aligned}
$$

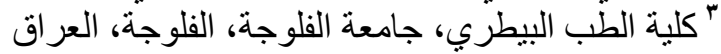

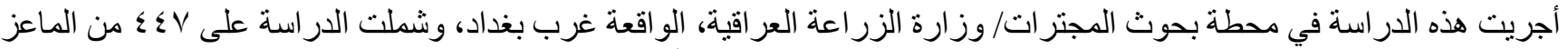

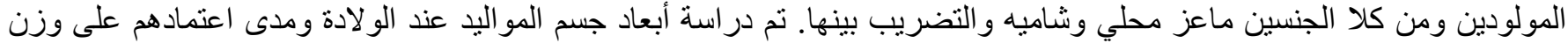

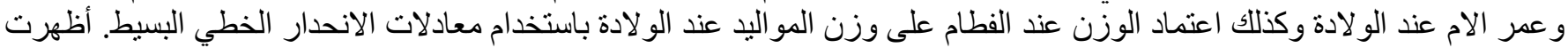

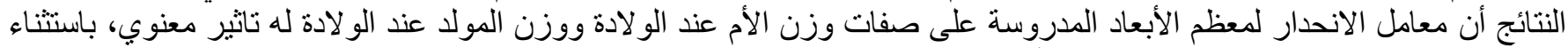

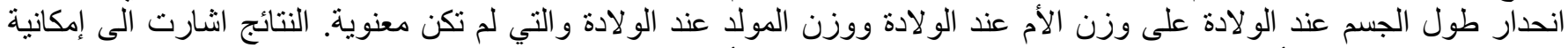

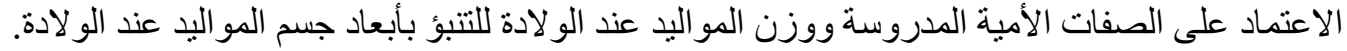

\section{Introduction}

The livestock is very important sector in its contribution to food security. Despite the estimated growth of this sector in the Arab world in general, estimated at $2.3 \%$ annually, production is still far below the potential and resources available. Therefore, in order to achieve qualitative leaps that meet the needs of society in general, it is necessary to overcome many deficiencies such as the spread of diseases, epidemics, underdevelopment of animal production systems and husbandry prevailing in the region (1).

Iraq constitute $4.5 \%$ of the total goat population in the Arab world (1). The increase in growth is a clear indication of the animal's ability to produce meat significantly and that the dimensions of the animal body in different ages including the birth stage is a strong and early signal of the 
potential of the animal on high fatting, its possible to take advantage of these traits in the conduct of selection to obtain the sires of future generations with desirable qualities (2). To find the best prediction equations to be a role in early farm animal selection programs, which effectively reduces the economic costs of raising farm animals. So, there is a need to develop prediction equations for body dimensions using independent variables that are repeatable and easily measured at the animal husbandry farms level and that was the aim of the study.

\section{Materials and methods}

This study was conducted at the ruminants' research station in Ekrkov located in the area within $23 \mathrm{~km}$ west of Baghdad, for the period from 1/11 / 2013-20/01/2014. The experiment was carried out to find out a prediction linear equation for body dimensions in goat kids. The research included 447 goat kids belong to (Iraqi Local, Shami and their crosses). Also, the study included the birth weight of the kids, the weaning weight of the kids, chest and abdominal circumference, body length and front height of the kids' body in addition to weight and age of the mother goats at birth.
The equations to predict some of the traits account depending on the simple linear regression and the use of coefficient of determination (R2) which estimated (3) to describe effects of factors on studied traits statistical analysis of the data using the SAS (4) program. The equations that describe the prediction are as follows:

$$
\begin{aligned}
& \hat{Y} x=a+b(x i) \\
& a=y--b x- \\
& \hat{Y}: \text { The predicted (dependent) trait. } \\
& a: y-\text { intercept of the slope line. } \\
& \text { b: The regression coefficient. } \\
& \text { Xi: The independent trait. }
\end{aligned}
$$

\section{Results and discussion}

\section{Birth and weaning weights}

It has been found that the average weight of dam at kidding, kids birth weight and kids weaning weight were $41.34,2.92$ and $15.53 \mathrm{~kg}$ respectively (Table 1 ). These results outweigh the findings of $(2,5)$ in their studies on local and Shami goats and their crosses.

Table 1: Mean \pm SE of dam and kids studying traits

\begin{tabular}{lc}
\hline Trait & Overall mean \pm SE \\
\hline Dams weight at kidding $(\mathrm{kg})$ & $41.345 \pm 2.78$ \\
Kids weight at birth $(\mathrm{kg})$ & $2.97 \pm 0.09$ \\
Kids weight at weaning $(\mathrm{kg})$ & $15.53 \pm 0.45$ \\
Kids Body length at birth $(\mathrm{cm})$ & $27.56 \pm 0.21$ \\
Kids Chest circumference at birth $(\mathrm{cm})$ & $31.52 \pm 0.20$ \\
Kids Abdominal circumference at birth (cm) & $31.54 \pm 0.25$ \\
Kids Front height of the kids body at birth $(\mathrm{cm})$ & $31.64 \pm 0.21$ \\
\hline
\end{tabular}

\section{Body dimensions at birth}

The results in table 1 show that overall ranges of body length, chest and abdominal circumference, and front height of the body at birth were $27.65,31.52,31.54$ and $31.64 \mathrm{~cm}$ sequentially, which were close results to $(5,6)$.

\section{Phenotypic correlations}

The analysis of data indicates that most of Phenotypic correlations between the four body dimensions at birth stage (body length, chest abdominal circumference, and front height of the body) were positive highly significant $(\mathrm{P}<0.01)$ the highest was between chest circumference and front height of the body (0.81), and the lowest was between abdominal circumference and body length (0.09) (Table 2). These results closed to the results of (7) in a study on Yankasu sheep. The phenotypic values of the two traits resulting from the total variations caused by genetic and environmental factors (8).

\section{Prediction equations}

The main concern of the paper was to obtain the prediction equations of studied traits. The prediction equations for body measurements of goat in Iraq (Table 3 ). (9) summarizes the linear relationship between most of traits as the regression equations ranged from nonsignificant to significant $(\mathrm{P}<0.05)$ depending to attachment $\mathrm{R} 2$ values. It has been found a significant regression to both birth and weaning weights of kids on kidding dam age with R2 equal to 0.74 and 0.69 respectively. And so was the regression factor of chest and abdominal circumference and front height of the body on kidding dam weight significant $(\mathrm{P}<0.05)$ with $\mathrm{R} 2$ equal to $0.65,0.60$ and 0.62 sequentially. Also, the significance of regression equations was observed in chest and abdominal circumference, and front height of the body on birth weight of kids which were about 0.66 , 0.62 and 0.64 R2 respectively. Otherwise, our results did not appear a significant regression neither for kid's birth and 
weaning weights on kidding dam weight, nor for body length at birth on both kidding dam weight and kid's weight at birth. Thus, the final result of $\mathrm{R} 2$ values indicate that 60 to $74 \%$ of the studied traits variable $(\mathrm{Y})$ belong to the variance of traits on which they descended (x).the accuracy of the equations used to predict the dimensions of the body through there regression on kidding dam weight and kids weight at birth have enormous economic importance in animal production, and the ability of animal producers has a great relationship with measurements of live body and growth characters, and its essential for all ideal animal production institutions, especially the developing world (10).

Table 2: Phenotypic correlations between kids body dimensions at birth

\begin{tabular}{lccc}
\hline Dimensions & Body length & Chest circumference & Abdominal circumference \\
\hline Front height & $0.70^{* *}$ & $0.81^{* *}$ & $0.49^{* *}$ \\
Body length & - & $0.80^{* *}$ & $0.09^{* *}$ \\
Chest circumference & - & - & $0.41^{* *}$ \\
\hline
\end{tabular}

$* *(\mathrm{P}<0.01)$.

Table 3: Prediction simple linear equations of studying traits

\begin{tabular}{|c|c|c|c|}
\hline Traits & & Regression & Coefficient of \\
\hline Dependent variable $(\mathrm{Y})$ & Independent variable $(\mathrm{X})$ & equation & determination (R2) \\
\hline Kids birth weight & Dam weight at kidding & $\hat{\mathrm{Y}}=1.818+0.032(\mathrm{X})$ & 0.34 \\
\hline Kids birth weight & Dam age at kidding & $\hat{\mathrm{Y}}=3.201+(-0.015)(\mathrm{X})$ & $0.74 *$ \\
\hline Kids weaning weight & Dam weight at kidding & $\hat{\mathrm{Y}}=12.28+0.08(\mathrm{X})$ & 0.42 \\
\hline Kids weaning weight & Dam age at kidding & $\hat{Y}=86.66+(-0.18)(X)$ & $0.69 *$ \\
\hline Body length at birth & Dam weight at kidding & $\hat{\mathrm{Y}}=27.14+0.01(\mathrm{X})$ & 0.56 \\
\hline Chest circumference at birth & Dam weight at kidding & $\hat{\mathrm{Y}}=13.69+(-0.004)(\mathrm{X})$ & $0.65 *$ \\
\hline Abdominal circumference at birth & Dam weight at kidding & $\hat{Y}=31.753+(-0.005)(X)$ & $0.60 *$ \\
\hline Front height at birth & Dam weight at kidding & $\hat{\mathrm{Y}}=30.16+0.036(\mathrm{X})$ & $0.62 *$ \\
\hline Body length at birth & Kids birth weight & $\hat{\mathrm{Y}}=20.85+2.137(\mathrm{X})$ & 0.55 \\
\hline Chest circumference at birth & Kids birth weight & $\hat{Y}=6.544+2.226(X)$ & $0.66 *$ \\
\hline Abdominal circumference at birth & Kids birth weight & $\hat{\mathrm{Y}}=6.112+2.368(\mathrm{X})$ & $0.62 *$ \\
\hline Front height at birth & Kids birth weight & $\hat{\mathrm{Y}}=24.27+2.349(\mathrm{X})$ & $0.64 *$ \\
\hline
\end{tabular}
$*(\mathrm{P}<0.05)$

\section{Conclusion}

We concluded that it is possible to depend on dam weight and age, and kid weight at birth characteristics to predict different kids body dimensions from using the prediction equations calculated in this study to reduce the economic cost of goat breeding and to use them in the goat early selection programs.

\section{References}

1. Arab Organization for Agriculture Development. A study of using modern technologies in animal production improvement in Arab region. Al-Khortoom, 2006.

2. Abdulrahman FY, Asofi MG, Jasim AK. A study of some productive traits in Local and Shami goats and their crosses. AL-Rafedain Agri J. 2006;34(2):30-36.

3. Al-Rawi KM. Introduction to statistic. Mosul: Dar Al Kutob for Printing and Publishing; 1983.
4. SAS. Statistical analysis system, user's guide for personal computers. New York: SAS Institute Inc. 2012.

5. Hermiz HN, Al-Kass JE, Hobi AA, Asofi MK. Genetic and phenotypic parameters of body weights in Iraqi Local Goat and their crosses with Damascus. J Duhok Univ. 2009;2(1):189-194.

6. Idriss SMT, Taha SA, Ajeel HM, Abdullah AN, Mustafa EK. Comparison of the productive and reproductive performance of Local and Shami goats in semi-intensive production conditions. Iraqi Agri J. 2009;14(1):31-40.

7. Afolayan RA, Adeyinka IA, Lakpini CAM. The estimation of live weight from body measurements in Yankasa sheep. Czech J Anim Sci. 2006;51(8):343-348.

8. Falconer DS, Mackay TFC. Introduction to quantitative genetics. $4^{\text {th }}$ ed. London: Longman Group Ltd. 1996.

9. Al-Rawi AA, Hermis HN, AL-Salman MH, Abdulhameed S. The amount and direction of the change in the dimensions of the body of Awassi sheep and the mix. Iraqi Agri J. 2002;5(1):42-50.

10. Umoh JA. Relationship between measurements and live weight of crossbreds Friesian White Fulani and Charolaise White Fulani cattle in Nigeria. Beitrage Trop Landwirthsch Vet Med. 1982;20:413-419. 